\title{
Sterically Demanding Diphosphonite Ligands - Synthesis and Application in Nickel-Catalyzed Isomerization of 2-Methyl-3-Butenenitrile
}

\author{
Jarl Ivar van der Vlugt, ${ }^{\text {a }}$ Alison C. Hewat, ${ }^{\mathrm{a}}$ Samuel Neto, ${ }^{\mathrm{a}}$ Rafael Sablong, ${ }^{\mathrm{a}}$ \\ Allison M. Mills, ${ }^{\mathrm{b}}$ Martin Lutz, ${ }^{\mathrm{b}}$ Anthony L. Spek, ${ }^{\mathrm{b}}$ Christian Müller, ${ }^{\mathrm{a}}$ \\ Dieter $\operatorname{Vog}^{\mathrm{a}, *}$ \\ a Laboratory for Homogeneous Catalysis, Schuit Institute for Catalysis, Eindhoven University of Technology, \\ Den Dolech 2, 5600 MB Eindhoven, The Netherlands \\ Fax: (+31)-40-245-5054, e-mail: d.vogt@tue.nl \\ b Department for Crystal and Structural Chemistry, Utrecht University, Padualaan 2, $3584 \mathrm{CH}$ Utrecht, The Netherlands
}

Received: December 23, 2003; Accepted: May 25, 2004

Dedicated to Professor Joachim Bargon (Universität Bonn) on the occasion of his $65^{\text {th }}$ birthday.

\begin{abstract}
The synthesis of a novel class of sterically demanding diphosphonites 1-8, based on rigid backbones, is described. The starting materials are all commercially available and the methodology allows for a modular approach. All ligands have been fully characterized, including an X-ray crystal structure for compound 1, 4,5-bis\{di[(2-tert-butyl)phenyl]phosphonito\}-9,9-dimethylxanthene. The coordination of these diphosphonite ligands towards $\mathrm{Ni}(\mathrm{II})$ and $\mathrm{Ni}(0)$ precursors is investigated, both by NMR spectroscopy as well as X-ray crystallography and compared with the behaviour of diphosphine ligands such as Xant-
\end{abstract}

phos. The molecular structure for complex 9, trans$\left[\mathrm{NiBr}_{2}(\mathbf{1})\right]$ is described in detail. The nickel-catalyzed isomerization of 2-methyl-3-butenenitrile to 3-pentenenitrile is studied, a relevant step in the industrially important hydrocyanation of butadiene (the DuPont adiponitrile process). Good activities and selectivities to the desired 3-pentenenitrile are obtained in this reversible $\mathrm{C}-\mathrm{C}$ bond activation reaction.

Keywords: hydrocyanation; isomerization; 2-methyl3-butenenitrile; nickel; P ligands

\section{Introduction}

The isomerization of the unsaturated nitrile 2-methyl-3butenenitrile is the key intermediate step in the hydrocyanation of butadiene to adiponitrile, a building block for nylon-6,6 production. ${ }^{[1]}$ Thorough insight into the steric and electronic factors which influence this reversible $\mathrm{C}-\mathrm{C}$ bond activation reaction, however, is still lacking. Recent results obtained in the hydrocyanation of various substrates have made clear that phosphorus ligands with rigid backbone structures are needed for a selective process. ${ }^{[2]}$ Strongly coordinating $\pi$-acceptor ligands, however, turned out to be unsuitable because of a tendency to form catalytically inactive Ni-bis-chelate complexes. On the other hand, this undesired side-reaction can be suppressed using sterically demanding ligands. ${ }^{[3]}$ With this in mind, we decided to explore the synthesis of new bulky diphosphonites based on rigid xanthene-derived backbones.

In the past decades, several new classes of phosphorus-containing ligands have been discovered. ${ }^{[4-6]}$ Most of these ligands either bear diphosphines ${ }^{[7-10]}$ or diphosphites $^{[11-13]}$ as the chelating group. However, only a few examples of diphosphonites have been reported in the literature to date. Both Reetz et al. and Zanotti-Gerosa et al. have published on the catalytic activity of various diphosphonites $^{[14]}$ based on known backbones. One of the more recent ligand systems used in homogeneous catalysis, such as hydroformylation and Pd-catalyzed $\mathrm{C}-\mathrm{C}$ coupling, is based on the xanthene backbone. The diphosphine ligands derived from this rigid backbone were first described by Haenel et al. ${ }^{[15]}$ Independently, the group of van Leeuwen focused on various transition metal-catalyzed reactions applying these ligands. ${ }^{[16]}$ The proposed strength of this class of ligands lies in the combination of a rigid backbone, the large natural bite angle, a limited number of possible coordination modes and possibly the favourable interaction of the oxygen in the backbone with the metal center.

Here we report on the synthesis of a new class of sterically constrained diphosphonites ${ }^{[17]}$ (Figure 1) based on the xanthene backbone, thereby combining all of the 


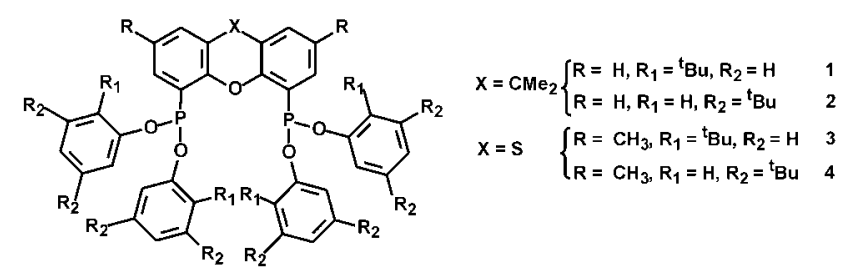

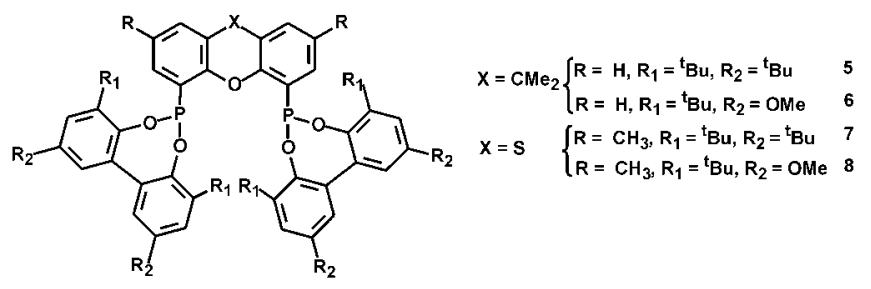

Figure 1.

aforementioned features. We have tested these novel ligands in the nickel-catalyzed isomerization of 2-methyl3-butenenitrile to 3-pentenenitrile. The results were compared with those from diphosphine analogues of the Xantphos ligand family.

\section{Results and Discussion}

\section{Synthesis of Diphosphonite Ligands}

The sterically constrained diphosphonites are obtained in two reaction steps, starting from the commercially available compounds 9,9-dimethylxanthene, phenoxathiin and various phenols (Scheme 1). ${ }^{[17]}$ As an intermediate precursor the bis-diethylamidophosphonitoxanthene was prepared. ${ }^{[18]}$ Subsequently, reaction with the desired phenolic compound yielded the diphosphonites $\mathbf{1 - 8}$ in good yields. Tetrazole was required as protonation agent, in order to force the reaction to go to completion. Diglyme was used as a polar, high-boiling solvent, enabling a reaction temperature of $150^{\circ} \mathrm{C}$. The reaction was followed by ${ }^{31} \mathrm{P}$ NMR spectroscopy. Compounds 1-8 were obtained as white or yellow solids and were fully characterized by ${ }^{1} \mathrm{H},{ }^{13} \mathrm{C}$ and ${ }^{31} \mathrm{P} \mathrm{NMR}$ spectroscopy, mass spectrometry as well as elemental analysis.

\section{X-Ray Crystallographic Study of Compound 1}

We were able to obtain single crystals of compound $\mathbf{1}$ suitable for X-ray analysis by recrystallization from hot acetonitrile. Compound $\mathbf{1}$ crystallizes as an acetonitrile solvate in the space group $P 2_{1} / \mathrm{c}$ with four molecules in the unit cell. The molecular structure of $\mathbf{1}$ is depicted in Figure 2 and indicates that the phenol groups are bent in an anti-parallel fashion and due to the steric bulk of the substitutents, no $\pi$-stacking as in the case of the

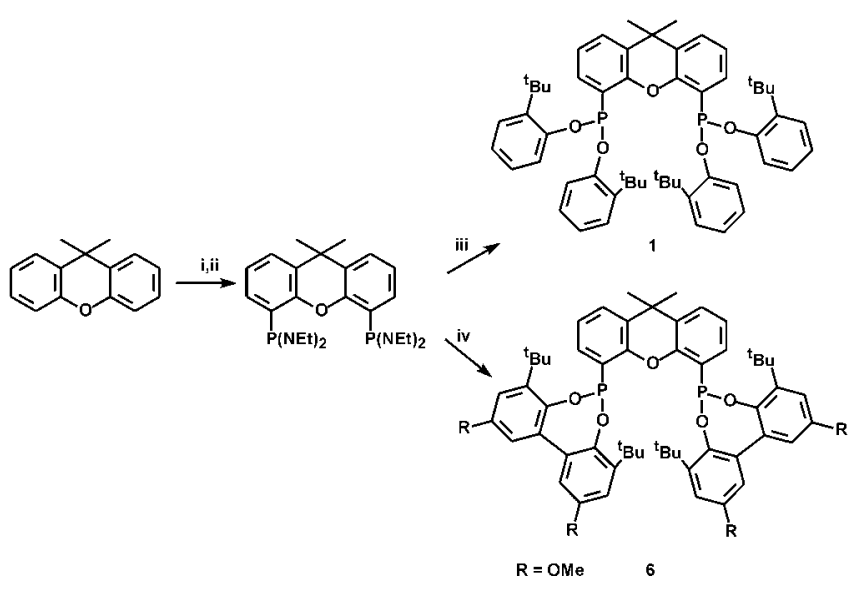

Scheme 1. Reaction scheme for the synthesis of compounds 1 and 6: i) $n$-BuLi, TMEDA, $\mathrm{Et}_{2} \mathrm{O},-40^{\circ} \mathrm{C}, 16 \mathrm{~h}$; ii) $\mathrm{ClP}\left(\mathrm{NEt}_{2}\right)_{2}$, pentane, $-60^{\circ} \mathrm{C}, 16 \mathrm{~h}$; iii) 2-tert-butylphenol (4 equivs.), diglyme, tetrazole, $\Delta$ (45\%); iv) $2,2^{\prime}$-dihydroxy-3,3'bis(tert-butyl)-5,5'-dimethoxy-1,1'-biphenyl, (4 equivs.) diglyme, tetrazole, $\Delta(87 \%)$.

Xantphos ligand is observed. ${ }^{[16]}$ The P1-P2 distance is 4.1299(8) $\AA$, slightly larger than found for a xanthenebased diphosphine. The phosphorus-oxygen bond lengths are 1.6496(12)-1.6570(12) $\AA$, comparable to bond lengths in known phosphite systems. The xanthene backbone is only slightly twisted with an interplanar angle of $8.33(10)^{\circ}$ which is in accordance with the absence of any stacking of the aromatic rings due to steric congestion.[19]

\section{X-Ray Crystallographic Study of Ni(II) Complex of Diphosphonite Ligand 1}

In the Ni-catalyzed hydrocyanation of styrene derivatives, RajanBabu et al. have shown that both the catalytic resting state and the active species are $\mathrm{Ni}$ (II) complexes bearing only one chelating phosphorus ligand ('monochelate'). ${ }^{[20]}$ Nickel species containing two chelating ligands ('bis-chelates') have to be avoided, since formation of the substrate complex is most likely inhibited. We believe that our new, sterically demanding diphosphorus ligands offer new possibilities to prevent the formation of such undesired and catalytically inactive Ni-bis-chelate complexes.

In order to study the coordination behaviour of these novel diphosphonites and the influence of the steric bulk on the complex formation, we have prepared the nickel complex $\left[\mathrm{NiBr}_{2}(\mathbf{1})\right]$ by reaction of $\mathrm{Ni}(\mathrm{dme}) \mathrm{Br}_{2}(\mathrm{dme}=$ dimethoxyethane) with ligand $\mathbf{1}$ in $\mathrm{THF}$ at $70^{\circ} \mathrm{C}$ for two days. Single crystals, suitable for X-ray analysis, were obtained for the paramagnetic, purple compound $\mathrm{NiBr}_{2}(\mathbf{1})$, by slow diffusion of pentane into an ether solution of this complex. The molecular structure of com- 


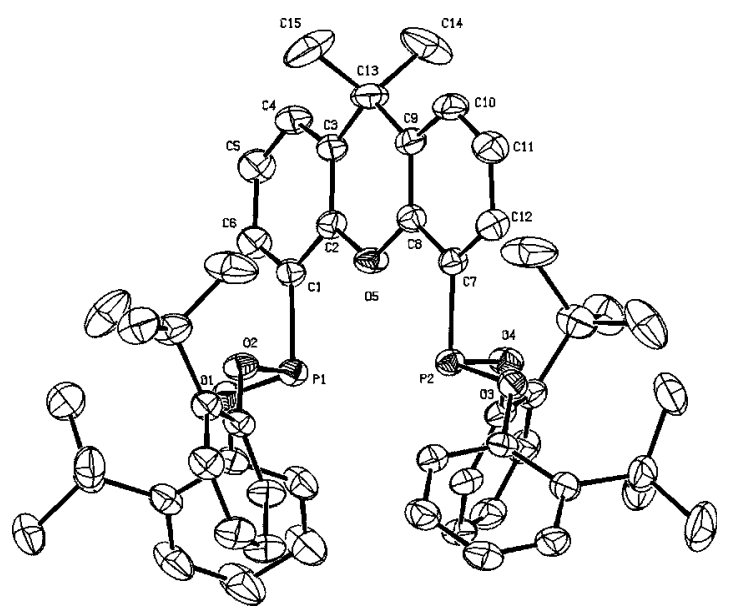

Figure 2. Displacement ellipsoid plot of compound 1, drawn at the $50 \%$ probability level. All hydrogen atoms and acetonitrile solvent molecules are omitted for clarity. Selected bond lengths $(\AA)$ angles, and torsion angles $\left({ }^{\circ}\right)$ : P1-O1 1.6570(12); P1-O2 1.6512(12); P2-O3 1.6503(13); P2-O4 1.6496(12); P1-C1 1.8252(17); P2-C7 1.8290(17); O5-C2 1.381(2); O5-C8 1.378(2); P1-P2 4.1298(8); O1-P1-O2 99.18(6); O3-P2-O4 98.09(7); O1-P1-C1 95.89(7); O2$\mathrm{P} 1-\mathrm{C} 1$ 95.22(7); O3-P2-C7 97.04(7); O4-P2-C7 94.60(7); C2-O5-C8 119.33(13); C3-C13-C9 110.34(15); C1-C2C3-C13 173.27(17); C7-C8-C9-C13 175.03(17).

plex 9 is shown in Figure 3, together with selected bond lengths and angles.

The geometry around the Ni-atom in complex 9 is distorted square planar with the phosphonite moieties coordinated in a mutual trans-fashion. This coordination mode has been observed before for Pd and $\mathrm{Rh}$ complexes. ${ }^{[21]}$ The observed bite angle $\mathrm{P} 1-\mathrm{Ni}-\mathrm{P} 2$, is 151.81(3) ${ }^{\circ}$, while the angle $\mathrm{Br} 1-\mathrm{Ni}-\mathrm{Br} 2$ is $163.073(18)^{\circ}$. The xanthene backbone is bent, as indicated by the interplanar angle of $27.65(12)^{\circ}$ between the two aromatic rings. This phenomenon is most likely caused by the substituents on the phenolic moieties. The $\mathrm{Ni}-\mathrm{Br}$ and the $\mathrm{Ni}-\mathrm{P}$ bond lengths are in their expected ranges. ${ }^{[22-25]}$ The intramolecular distance between the two phosphorus atoms is 4.2171(9) $\AA$, only slightly larger in comparison to the uncoordinated ligand (vide supra). All $\mathrm{P}-\mathrm{O}$ bond lengths are between $1.6020(16)$ and 1.6191(16) $\AA$. The distance between the nickel and the oxygen atom in the backbone bridge is found to be 2.6137(16) $\AA$. Together with the fact that the four angles $\mathrm{P}-\mathrm{Ni}-\mathrm{Br}$ are in the range of $86.78(2)$ to $98.56(2)^{\circ}$, the oxygen can be considered to occupy the apical position of a square pyramid. However, any interaction between the nickel and the oxygen cannot be presumed on the basis of the crystal structure alone. From the Cambridge Crystallographic Database ${ }^{[26]}$ it appears that nickel complexes with coordinated ether moieties show an average $\mathrm{Ni}-\mathrm{O}$ bond length of $2.15 \AA$.

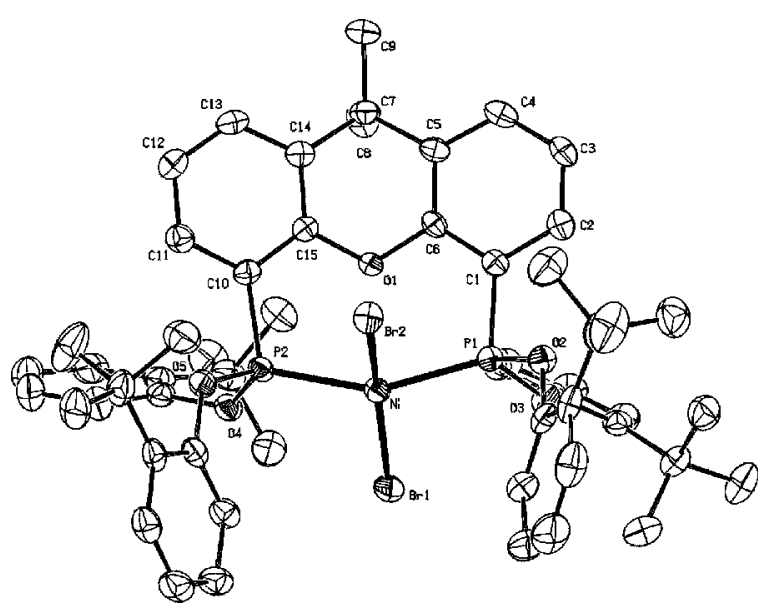

Figure 3. Displacement ellipsoid plot of complex 9, trans$\left[\mathrm{NiBr}_{2}(\mathbf{1})\right]$, drawn at the $50 \%$ probability level. All hydrogen atoms are omitted for clarity. Selected bond lengths ( $)$, angles, and torsion angles $\left(^{\circ}\right)$ : Ni-P1 2.1632(7); Ni-P2 2.1848(7); Ni-Br1 2.2886(4); Ni-Br2 2.3110(4); P1-O2 $1.6020(16) ; \mathrm{P} 1-\mathrm{O} 3$ 1.6060(17); $\mathrm{P} 1-\mathrm{C} 1$ 1.808(2); $\mathrm{P} 2-\mathrm{O} 4$ 1.6191(16); P2-O5 1.6167(17); P2-C10 1.814(2); O1-C6 1.393(3); O1-C15 1.393(3); Ni-O1 2.6137(16); P1-P2 4.2171(9); $\mathrm{Br} 1-\mathrm{Ni}-\mathrm{Br} 2$ 163.073(18); $\mathrm{P} 1-\mathrm{Ni}-\mathrm{P} 2$ 151.81(3); $\mathrm{Br} 1-\mathrm{Ni}-\mathrm{P} 1 \quad 94.69(2) ; \quad \mathrm{Br} 1-\mathrm{Ni}-\mathrm{P} 2$ 98.56(2); $\mathrm{Br} 2-\mathrm{Ni}-\mathrm{P} 1$ 87.68(2); $\mathrm{Br} 2-\mathrm{Ni}-\mathrm{P} 2$ 86.78(2); O2-P1-O3 96.66(9); O4$\mathrm{P} 2-\mathrm{O} 5 \quad 106.55(9) ; \quad \mathrm{Ni}-\mathrm{P} 1-\mathrm{O} 2 \quad 121.41(7) ; \quad \mathrm{Ni}-\mathrm{P} 1-\mathrm{O} 3$ 121.38(6); Ni-P2-O4 113.46(7); Ni-P2-O5 121.14(7); $\mathrm{Ni}-\mathrm{P} 1-\mathrm{C} 1$ 109.00(8); Ni-P2-C10 109.24(8); C6-O1-C15 116.87(16); C5-C7-C14 108.25(19); O2-P1-C1 100.09(9); $\mathrm{O} 3-\mathrm{P} 1-\mathrm{C} 1$ 105.38(10); O4-P2-C10 104.89(10); O5-P2C10 99.62(10); C1-C6-C5-C7 179.1(2); C10-C15-C14C7 174.4(2).

\section{Nickel(0) Complexes with Diphosphonite Ligands}

We further investigated the coordination behaviour of the new diphosphonites towards $\mathrm{Ni}(0)$. $\mathrm{Ni}(\operatorname{cod})_{2}$ was used as a nickel(0) source and reactions with some of these ligands were carried out. Table 1 lists the chemical shifts observed in the ${ }^{31} \mathrm{P}$ NMR spectrum for the complexes obtained by reaction of equimolar amounts of ligand and $\mathrm{Ni}(\operatorname{cod})_{2}$ at room temperature. Interestingly, in the cases of ligands $\mathbf{2}$ and $\mathbf{4}$ the Ni monochelate complexes were indeed formed quantitatively, showing one singlet at approximately $\delta=160 \mathrm{ppm}$ in the ${ }^{31} \mathrm{P}$ NMR spectrum. The more sterically demanding phosphonites $\mathbf{1}, \mathbf{5}, \mathbf{6}$ and $\mathbf{8}$ produced the desired Ni monochelate complexes upon heating or prolonged reaction times of up to 48 hours.

To confirm the presence of the monochelate in the case of ligand $4, \mathrm{PPh}_{3}$ was added to $\mathrm{Ni}(\operatorname{cod})(4)$ (species A). $\mathrm{PPh}_{3}$ coordinated to the $\mathrm{Ni}$ center without displacing the bidentate phosphonite. However, a trigonal planar complex containing a single $\mathrm{PPh}_{3}$ ligand and the diphosphonite, species B, was not observed. We attribute the triplet in the ${ }^{31} \mathrm{P}$ NMR spectrum at $\delta=139.9 \mathrm{ppm}$ (phos- 
Table 1. ${ }^{31} \mathrm{P}$ NMR chemical shifts of $\mathrm{Ni}(\operatorname{cod})(\mathrm{PP})$ complexes obtained with diphosphonite ligands.

\begin{tabular}{lll}
\hline Ligand & Free ligand & $\mathrm{Ni}(0)$ complex \\
\hline 1 & $147.8(\mathrm{~s})$ & $148.5(\mathrm{~s})$ \\
2 & $148.2(\mathrm{~s})$ & $158.0(\mathrm{~s})$ \\
4 & $144.7(\mathrm{~s})$ & $157.9(\mathrm{~s})$ \\
5 & $169.4(\mathrm{~s})$ & $163.4(\mathrm{~s})$ \\
6 & $168.5(\mathrm{~s})$ & $164.0(\mathrm{~s})$ \\
8 & $167.0(\mathrm{~s})$ & $163.4(\mathrm{~s})$ \\
\hline
\end{tabular}

phonite region) to $\mathrm{Ni}\left(\mathrm{PPh}_{3}\right)_{2}(\mathbf{4})$ (species $\left.\mathbf{C}\right)$, as depicted in Scheme 2.

Species $\mathbf{C}$ is highly symmetrical because the two phosphorus atoms of the diphosphonite unit remain equivalent. While the triplet in the phosphonite region was well resolved, the corresponding signal in the phosphine region appears as a broad singlet at $\delta=35 \mathrm{ppm}$, with an integrated ratio of $1: 1$. The broadness of the singlet is most likely due to rapid exchange with free $\mathrm{PPh}_{3}{ }^{\left[{ }^{[27]}\right.}$ Upon addition of more than 2 equivalents of $\mathrm{PPh}_{3}$, the starting material A quantitatively disappeared. Besides $\mathbf{C}$ the formation of a new species was now observed in the ${ }^{31} \mathrm{P}$ NMR spectrum as a singlet at $\delta=25.8 \mathrm{ppm}$. We attribute this resonance to the compound $\mathrm{Ni}\left(\mathrm{PPh}_{3}\right)_{3}$. ${ }^{[27 \mathrm{a}]}$ For details on chemical shifts see Table 2.

\section{Nickel Complexes with Constrained Diphosphine Analogues}

In order to make comparisons between the coordination chemistry of the novel diphosphonites and diphosphines we performed similar reactions with known bidentate phosphine systems. In the past decade, Xantphos and several of its derivatives have been extensively investigated as ligands in a number of transition metal-catalyzed reactions. ${ }^{[28]} \mathrm{POP}-X a n t p h o s$ is a derivative which includes a rigid phenoxaphosphine cycle (Figure 4). ${ }^{[29]}$ Based on molecular modelling calculations, the natural
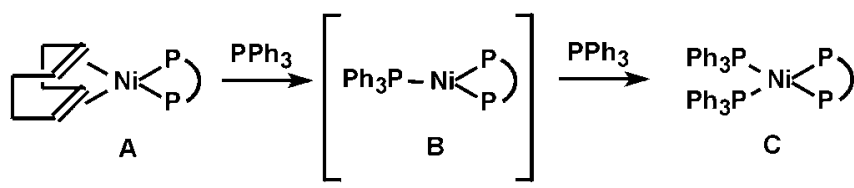

Scheme 2. Addition of $\mathrm{PPh}_{3}$ to the monochelate complex of diphosphonite ligand 4. bite angle is $123.1^{\circ}$ with a flexibility range of $107-142^{\circ}$ and the ligand has been shown to be active in the hydroformylation of 1-octene and trans-2- and -4-octene. The complexation behaviour of these ligands with nickelprecursors was investigated by ${ }^{31} \mathrm{P}$ NMR spectroscopy. Table 3 summarizes the chemical shifts obtained for the nickel complexes formed in the presence of these diphosphines. They are comparable to reported literature data on related systems. ${ }^{[3,17 a, 30]}$

\section{Nickel-Catalyzed Isomerization of 2-Methyl-3- Butenenitrile with Diphosphonites}

In current industrial practice, the reaction of butadiene with $\mathrm{HCN}$ produces initially 2-methyl-3-butenenitrile $(2 \mathrm{M} 3 \mathrm{BN})$ together with the desired linear 3-pentenenitrile (3PN) in a kinetically controlled ratio of 30:70 [Eq. (1)]. ${ }^{[1]}$ This ratio, which is a kinetic rather than a thermodynamic distribution, depends on the nature of the catalyst and therefore justifies the search for systems that are able to isomerize the unwanted product $2 \mathrm{M} 3 \mathrm{BN}$ to the more useful 3PN, which can then be further converted to adiponitrile. The catalyst systems currently used in industry (e.g., Ni/tris-kresyl phosphite) produce the isomers $3 \mathrm{PN}$ and $2 \mathrm{M} 3 \mathrm{BN}$ finally after isomerization in a ratio which is close to the thermodynamic one of 93:7 (vide infra).

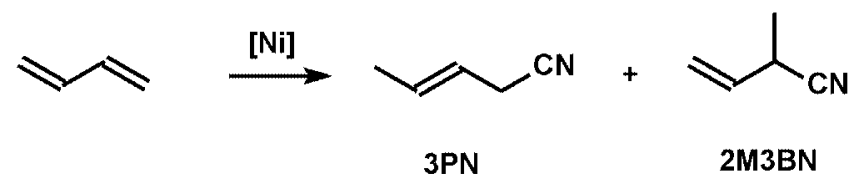

Scheme 3 illustrates the possible isomerization reactions that can occur. 2M3BN can undergo either unwanted double bond migration-isomerization $(\mathbf{E})$ to
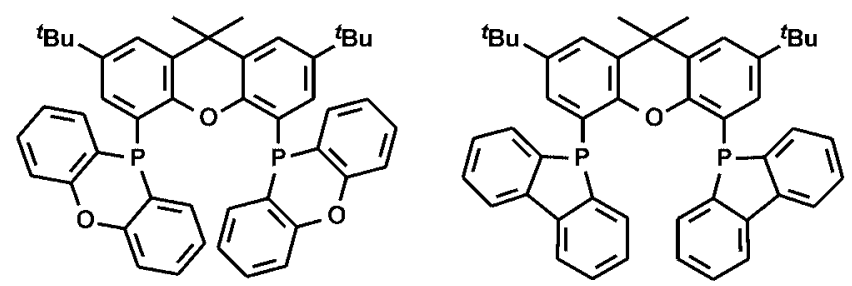

Figure 4. Representation of ligand POP-Xantphos (left) and DBP-Xantphos (right).

Table 2. Complexes formed after addition of $\mathrm{PPh}_{3}$ to monochelate complex of diphosphonite ligand 4.

\begin{tabular}{lllll}
\hline & $(\mathrm{cod}) \mathrm{Ni}(4)$ & $\mathrm{Ni}\left(\mathrm{PPh}_{3}\right)_{2}(4)$ & $\mathrm{Ni}\left(\mathrm{PPh}_{3}\right)_{2}(4)$ & $\mathrm{Ni}(\mathrm{PPh})_{3}$ \\
\hline$\delta{ }^{31} \mathrm{P}\left\{{ }^{1} \mathrm{H}\right\} \mathrm{NMR}$ & $157.9(\mathrm{~s})$ & $139.9(\mathrm{t})$ & $35 \mathrm{ppm}($ br s $)$ & $25.8(\mathrm{~s})$ \\
& & ${ }^{2} J_{\mathrm{PP}}=57(\mathrm{~Hz})$ & & \\
& & & \\
\hline
\end{tabular}


Table 3. ${ }^{31} \mathrm{P}\left\{{ }^{1} \mathrm{H}\right\}$ NMR chemical shifts of diphosphine containing complexes.

\begin{tabular}{llll}
\hline Ligand & $\delta$ Ligand & $\delta$ Monochelate & $\delta$ Bischelate \\
\hline DPEphos & -16.3 & $33.1(\mathrm{~s})$ & $15.5(\mathrm{br} \mathrm{s})$ \\
Sixantphos & -17.6 & $26.5(\mathrm{br} \mathrm{s})$ & $16.0(\mathrm{br}), 13.5(\mathrm{br})$ \\
Thixantphos & -17.3 & $26.1(\mathrm{~s})$ & $15.0(\mathrm{~m}), 11.7(\mathrm{~m})$ \\
Xantphos & -17.5 & 26.5 & $11.1(\mathrm{~m}, \mathrm{br}), 9.8(\mathrm{~m}, \mathrm{br})$ \\
POP-Xantphos & -69.9 & not observed & $-26.7\left(\mathrm{~m},{ }^{2} J_{\mathrm{P}-\mathrm{P}}=63 \mathrm{~Hz}\right)$ \\
& & & $-29.8\left(\mathrm{~m},{ }^{2} J_{\mathrm{P}-\mathrm{P}}=63 \mathrm{~Hz}\right)$ \\
\hline
\end{tabular}

the conjugated internal alkene 2-methyl-2-butenenitrile $(2 \mathrm{M} 2 \mathrm{BN})$ or skeletal isomerization $(\mathbf{D})$ to the desired linear 3PN. The latter reaction involves a reversible $\mathrm{C}-\mathrm{CN}$ bond activation reaction at the metal center. Subsequent double bond isomerization $(\mathbf{F})$ of $3 \mathrm{PN}$ leads to the likewise unwanted thermodynamically favored 2pentenenitrile (2PN). Furthermore, $3 \mathrm{PN}$ can also undergo kinetically controlled isomerization $(\mathbf{G})$ to the terminal 4-pentenenitrile (4PN), which could lead to adiponitrile under hydrocyanation conditions. Coordination of a Lewis acid to the nitrile function has been proposed to explain the observed preference. ${ }^{[31]}$

Isomerization reactions of unsaturated substrates with $\mathrm{Ni}(0)$ complexes based on monodentate phosphites as well as bidentate phosphines have been extensively investigated. $^{[32,33]}$ This reaction is normally facilitated by the use of Lewis acids such as $\mathrm{ZnCl}_{2}, \mathrm{BPh}_{3}$ or $\mathrm{AlCl}_{3}$. The isomerization leads to a mixture of $3 \mathrm{PN}: 2 \mathrm{M} 3 \mathrm{BN}$ in the thermodynamic ratio of 93:7. We are currently exploring a further account on the reversibility of substrate coordination to such nickel-complexes and will show the implications for these $\mathrm{C}-\mathrm{C}$ bond activation/formation reactions in a forthcoming communication. ${ }^{[34]}$

Given the promising X-ray crystallographic study on the $\left[\mathrm{NiBr}_{2}(1)\right]$ complex as well as the NMR study on the formation of the monochelate $\mathrm{Ni}(\mathrm{cod})$ (ligand) complexes described, we were interested in the application of these novel diphosphonite ligands in the nickel-catalyzed isomerization of unsaturated nitriles, with $2 \mathrm{M} 3 \mathrm{BN}$ as an important substrate in the Ni-catalyzed hydrocyanation of butadiene.

The newly designed ligands were tested in the isomerization of $2 \mathrm{M} 3 \mathrm{BN}$ in toluene at $90^{\circ} \mathrm{C}$, using $\mathrm{Ni}(\operatorname{cod})_{2}$ as

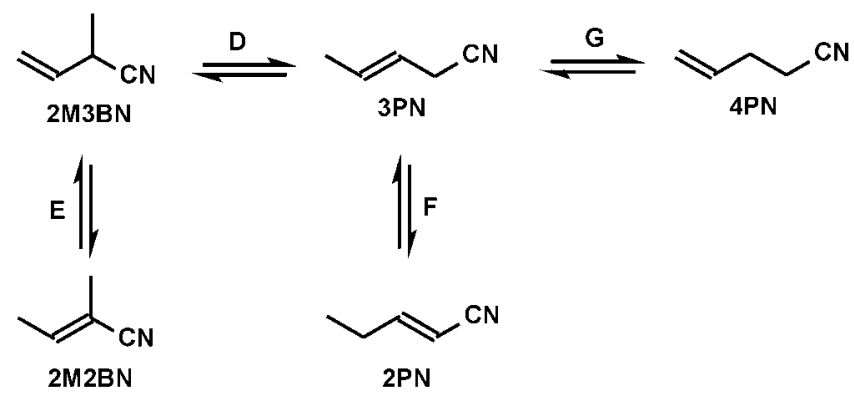

Scheme 3. Isomerization scheme for $2 \mathrm{M} 3 \mathrm{BN}$.
$(\mathrm{Ni}(\mathrm{O})$ precursor. Furthermore, the effect of additional Lewis acid was studied. Selectivities to $2 \mathrm{M} 2 \mathrm{BN}$ and $2 \mathrm{PN}$ were not independently determined; selectivities refer to the GC area percent of $3 \mathrm{PN}$ as a percentage of all observed products. Table 4 summarizes the results of catalytic tests performed with these ligands in the absence of Lewis acid and at two different preformation times, at room temperature.

Nickel complexes containing either diphosphonite 2 or $\mathbf{4}$ give close to quantitative conversion and selectivities of up to $74 \%$ for 3PN. Ligands 2 and $\mathbf{4}$ are the least sterically hindered ligands from the newly developed diphosphonite class, since the tert-butyl substituents are at the meta positions of the phenyl moiety. The complexation with $\mathrm{Ni}(\operatorname{cod})_{2}$ is almost instantaneous at room temperature with the compounds 2 and $\mathbf{4}$, resulting in monochelate complexes. All other sterically demanding ligands show little if any activity, probably due to insufficient preformation, yielding a low concentration of the active nickel catalyst. The catalytic system comprising ligand $\mathbf{1}$ however, does yield 3PN in very good selectivity (92\%). In order to promote the formation of the active nickel complex, more drastic preformation conditions were applied: The preformation time was increased to one hour after which the reaction temperature was set at $90^{\circ} \mathrm{C}$.

Once again, the least bulky ligands $\mathbf{2}$ and $\mathbf{4}$ give the most active nickel catalysts, with almost quantitative conversion, although selectivities are slightly reduced, due to consecutive isomerization to the inactive $2 \mathrm{PN}$. The highest selectivity is obtained with the xanthene backbone $(61 \%)$ versus the phenoxathiin backbone (51\%). The catalysts formed with either ligand 5 or 6 benefit from the longer preformation time and consequently, the conversion increases significantly from about $10 \%$ (vide supra) to $35 \%$, while selectivities of up to $85 \%$ are observed.

We also investigated the effect of Lewis acids on the isomerization of $2 \mathrm{M} 3 \mathrm{BN}$ with the same nickel-based catalytic systems, adding $\mathrm{AlCl}_{3}$ to the reaction mixture. The activities of the nickel catalysts derived from ligand $\mathbf{2}$ or $\mathbf{4}$ dropped only slightly, due to the presence of potentially coordinating Lewis acid. The selectivity to the linear product 3PN, however, decreased almost to zero, while formation of $2 \mathrm{PN}$ was favoured and this turned out to be the main product after one hour of re- 
Table 4. Isomerization of $2 \mathrm{M} 3 \mathrm{BN}$ in the absence of Lewis acid at different preformation times. ${ }^{[\mathrm{a}}$

\begin{tabular}{|c|c|c|c|c|}
\hline Ligand & Preformation time [min] & Conversion $[\%]^{[\mathrm{b}]}$ & Yield of 3PN [\% $]^{[\mathrm{b}]}$ & Selectivity for $3 \mathrm{PN}[\%]^{[\mathrm{b}]}$ \\
\hline 1 & 60 & 15 & 14 & 92 \\
\hline 2 & 60 & 97 & 72 & 74 \\
\hline 2 & 15 & 97 & 59 & 61 \\
\hline 4 & 60 & 98 & 55 & 57 \\
\hline 4 & 15 & 98 & 50 & 51 \\
\hline 5 & 15 & 10 & 9 & 82 \\
\hline 5 & 60 & 36 & 29 & 79 \\
\hline 6 & 15 & 9 & 8 & 89 \\
\hline 6 & 60 & 34 & 29 & 85 \\
\hline
\end{tabular}

[a] Reaction conditions: $2 \mathrm{~mL}$ toluene, $\mathrm{Ni}(\operatorname{cod})_{2}(20 \mathrm{mg}, 72.7 \mu \mathrm{mol}), \mathrm{Ni} / \mathrm{L} / \mathrm{S}=1 / 1 / 40, T=90^{\circ} \mathrm{C}, t=1 \mathrm{~h}$.

${ }^{\text {[b] }}$ Determined by GC.

action. This can be attributed to an acceleration of this consecutive double bond isomerization reaction owing to the presence of the Lewis acid, meaning that $3 \mathrm{PN}$ is formed but subsequently isomerized to the more stable thermodynamic product.

The other more sterically hindered diphosphonite ligands do not react with $\mathrm{AlCl}_{3}$ at room temperature, but in view of the lower activity of their nickel complexes in 2M3BN isomerization, possible Lewis acid interaction at reaction temperature $\left(90^{\circ} \mathrm{C}\right)$ cannot be ruled out.

\section{Nickel-Catalyzed Isomerization of 2-Methyl-3- Butenenitrile with Diphosphine Ligands}

We explored the isomerization capabilities of several $\mathrm{Ni}$ complexes with some xanthene derived diphosphine ligands [POP-Xantphos, DBP-Xantphos ${ }^{[29]}$ and 2,7-(ditert-butyl)Xantphos] as well, for which the results are listed in Table 5. As was observed in preliminary ${ }^{31} \mathrm{P}$ NMR studies, these ligands readily form bischelates. The substrate was hence directly added to the catalyst.

The most flexible ligand ( $t$-Bu-Xantphos) affords the highest conversion (98\%), whereas the lowest conversion $(31 \%)$ is obtained with the most rigid ligand (DBP-Xantphos). The best selectivity (71\%) and high conversion (89\%), however, is obtained with POP-Xant- phos. The difference in selectivity could be due to the slightly more electron-withdrawing character of the phosphorus heterocycle. The isomerization with DBPXantphos yielded a high proportion of the thermodynamic product $2 \mathrm{PN}$. Because of the irreversible formation of stable alkylnickel complexes with this internal alkene, the catalyst becomes inactive, most likely causing the conversion to be low. ${ }^{[35]}$ In experiments carried out with $t$-Bu-Xantphos and POP-Xantphos, the proportion of $2 \mathrm{PN}$ is quite high compared to $2 \mathrm{M} 2 \mathrm{BN}$. Because formation of $2 \mathrm{PN}$ results from $3 \mathrm{PN}$ double bond isomerization, limiting the reaction time, and thus conversion, may contribute to optimize the selectivity towards 3PN.

Comparative reactions were carried out with Xantphos, as a good conversion (98\%) and a good selectivity (75\%) were obtained at $90^{\circ} \mathrm{C}$ after 90 minutes (Table 6).

Reducing the reaction time from 90 to 15 minutes led to lower conversion (from almost $98 \%$ to nearly $67 \%$ ) without much effect on the selectivity. In the same way, reducing the reaction temperature from $90^{\circ} \mathrm{C}$ to $60{ }^{\circ} \mathrm{C}$ lowered the conversion to $50 \%$ as expected, but also the selectivity diminished (to $39 \%$ ). To explain this result, it seems plausible that the temperature effect on the rate of double bond isomerization is different than for the isomerization of the internal alkene. The rate of this latter type of isomerization could greatly benefit from a set increase in temperature, whereas the double-bond isomerization would only slightly rise.

Table 5. Isomerization of $2 \mathrm{M} 3 \mathrm{BN}$ using POP-Xantphos type ligands in absence of Lewis Acid. ${ }^{[a]}$

\begin{tabular}{|c|c|c|c|c|c|}
\hline Ligand & $\begin{array}{l}\text { Conversion } \\
{[\%]^{[\mathrm{b}]}}\end{array}$ & $\begin{array}{l}\text { Yield of } \\
\text { 3PN [\% }]^{[b]}\end{array}$ & $\begin{array}{l}\text { Selectivity } \\
\text { for 3PN [\% }]^{[\mathrm{b}]}\end{array}$ & $\begin{array}{l}\text { Selectivity } \\
\text { for } 2 \mathrm{M} 2 \mathrm{BN}[\%]^{[\mathrm{b}]}\end{array}$ & $\begin{array}{l}\text { Selectivity } \\
\text { for } 2 \mathrm{PN}[\%]^{[\mathrm{b}]}\end{array}$ \\
\hline DBP-Xantphos & 30.6 & 9.9 & 32.5 & 7.9 & 59.6 \\
\hline$t$-Bu-Xantphos & 97.9 & 63.3 & 64.7 & 7.9 & 27.6 \\
\hline POP-Xantphos & 89.0 & 63.5 & 71.4 & 3.6 & 25.1 \\
\hline
\end{tabular}

${ }^{[a]}$ Reaction conditions: $\mathrm{Ni}(\operatorname{cod})_{2}(9 \mathrm{mg}, 32.7 \mu \mathrm{mol})$ in $1 \mathrm{~mL}$ toluene, $T=90^{\circ} \mathrm{C}, t=1 \mathrm{~h}$; Ni/L/S: $1 / 0.5 / 40$; no catalyst preformation.

${ }^{[b]}$ Determined by GC. 
Table 6. Isomerization of $2 \mathrm{M} 3 \mathrm{BN}$ using Xantphos in the absence of Lewis acid. ${ }^{[\mathrm{a}]}$

\begin{tabular}{|c|c|c|c|c|c|c|c|}
\hline Ligand & $t[\min ]$ & $T\left[{ }^{\circ} \mathrm{C}\right]$ & $\begin{array}{l}\text { Conversion } \\
{[\%]^{[b]}}\end{array}$ & $\begin{array}{l}\text { Yield of } \\
3 P N[\%]^{[b]}\end{array}$ & $\begin{array}{l}\text { Selectivity } \\
\text { for 3PN [\% }]^{[\mathrm{b}]}\end{array}$ & $\begin{array}{l}\text { Selectivity } \\
\text { for } 2 \mathrm{M} 2 \mathrm{BN}[\%]^{[\mathrm{b}]}\end{array}$ & $\begin{array}{l}\text { Selectivity } \\
\text { for } 2 \mathrm{PN}[\%]^{[\mathrm{b}]}\end{array}$ \\
\hline Xantphos & 15 & 90 & 66.7 & 48.2 & 72.3 & 7.9 & 19.9 \\
\hline Xantphos & 90 & 90 & 97.5 & 73.1 & 75.0 & 7.2 & 17.9 \\
\hline Xantphos & 90 & 60 & 50.8 & 19.8 & 39.0 & 10.9 & 50.1 \\
\hline
\end{tabular}

(a) Reaction conditions: $\mathrm{Ni}(\mathrm{cod})_{2}(9 \mathrm{mg}, 32.7 \mu \mathrm{mol})$ in $1 \mathrm{~mL}$ toluene; Ni/Xantphos/S/: 1/1/40/1.05; preformation time $10 \mathrm{~min}$.

${ }^{[b]}$ Determined by GC.

\section{Conclusions}

In summary, we have reported on the synthesis of a novel class of sterically constrained diphosphonite compounds $1-8$ based on rigid backbones. The coordination behaviour of these ligands towards $\mathrm{Ni}(\mathrm{II})$ and $\mathrm{Ni}(0)$ has been studied by means of NMR spectroscopy and is compared with that of related diphosphine ligands. We observed sole formation of monochelate complexes in the case of the diphosphonite ligands. The molecular structure of the $\mathrm{Ni}(\mathrm{II})$ complex $\left[\mathrm{NiBr}_{2}(\mathbf{1})\right]$ was elucidated by X-ray crystallography. In the nickel-catalyzed isomerization of 2-methyl-3-butenenitrile, these ligands show good selectivities towards the desired linear 3-pentenenitrile. A more detailed study on the influence of the different reaction parameters is currently underway. Recently we finished a study on the coordination behaviour of these diphosphonites to various transition metals other than nickel ${ }^{[21]}$ as well as on the application of the diphosphonites in the rhodium-catalyzed hydroformylation of higher alkenes. ${ }^{[36]}$

\section{Experimental Section}

\section{General}

All chemicals were purchased from Aldrich Chemical Co., Acros or Merck and used as received. All preparations were carried out under an argon atmosphere using standard Schlenk techniques. Solvents were distilled from sodium/benzophenone (THF, ether, toluene, toluene- $d_{8}$, hexanes and ethanol) or calcium hydride $\left(\mathrm{CH}_{2} \mathrm{Cl}_{2}\right.$ and $\left.\mathrm{CDCl}_{3}\right)$ prior to use. All glassware was dried by heating under vacuum. The NMR spectra were recorded on a Varian Gemini $300 \mathrm{MHz}$ or Varian Mercury $400 \mathrm{MHz}$ spectrometer with both the ${ }^{31} \mathrm{P}$ and ${ }^{13} \mathrm{C}$ spectra being measured in the ${ }^{1} \mathrm{H}$ decoupled mode. Chemical shifts are given in ppm referenced to solvent $\left({ }^{1} \mathrm{H},{ }^{13} \mathrm{C}\right)$ or an $85 \%$ solution of $\mathrm{H}_{3} \mathrm{PO}_{4}\left({ }^{31} \mathrm{P}\right)$. GC were recorded on a Shimadzu 17A Chromatograph equipped with a Cp-wax $58 \mathrm{CB}$ column. Elemental analysis was performed on a Perkin Elmer 2400, Series II CHNS/O Analyzer. Mass spectrometry (MALDI-TOF) was performed on a Voyager-DE ${ }^{\mathrm{TM}}$ Pro (Perspective Biosystems) and Biospectrometry ${ }^{\mathrm{TM}}$ Workstation. $\mathrm{NiBr}_{2}$ (dimethoxyethane $)^{[20]}$ and $\mathrm{Ni}(\mathrm{cod})_{2}{ }^{[37]}$ were synthesized according to literature procedures.

\section{2,2'-Dihydroxy-3,3'-di-tert-butyl-5,5' -dimethoxy-1,1'- biphenyl (A)}

A solution of 3-tert-butyl-4-hydroxyanisole (10 g) in methanol $(300 \mathrm{~mL})$ was prepared and a solution of $\mathrm{KOH}(11.07 \mathrm{~g})$ and $\mathrm{K}_{3} \mathrm{Fe}(\mathrm{CN})_{6}(18.3 \mathrm{~g})$ in water $(300 \mathrm{~mL})$ was added dropwise over $1 \mathrm{~h}$ at room temperature. The mixture was stirred for 2 hours before the addition of $200 \mathrm{~mL}$ of water. The suspension was extracted with $500 \mathrm{~mL}$ of ethyl acetate twice. The aqueous solution was extracted with $150 \mathrm{~mL}$ of ether and the organic phases were combined and washed with $200 \mathrm{~mL}$ of saturated brine. The organic phase was dried over $\mathrm{Na}_{2} \mathrm{SO}_{4}$. Removal of the solvents under vacuum afforded a light brown solid. Washing with $n$-hexane resulted in an off-white powder; yield: $19.60 \mathrm{~g}(98 \%) .{ }^{1} \mathrm{H} \mathrm{NMR}\left(400 \mathrm{MHz}, \mathrm{CD}_{2} \mathrm{Cl}_{2}\right): \delta=6.96(\mathrm{~d}, 2 \mathrm{H}$, $J=3.2 \mathrm{~Hz}), 6.62(\mathrm{~d}, 2 \mathrm{H}, J=3.2 \mathrm{~Hz}), 4.64(\mathrm{~s}, 2 \mathrm{H}, \mathrm{OH}), 3.77(\mathrm{~s}$, $6 \mathrm{H}, \mathrm{OMe}), 1.43$ (s, 18H, $t$-Bu); ${ }^{13} \mathrm{C}$ NMR $\left(100 \mathrm{MHz}, \mathrm{C}_{6} \mathrm{D}_{6}\right)$ : $\delta=153.4,146.1,139.2,123.5,115.5,112.0,56.0,35.4,29.7$; anal. calcd. for $\mathrm{C}_{22} \mathrm{H}_{30} \mathrm{O}_{4}$ : C 73.4, H 8.4; found: C 73.9, $\mathrm{H}$ 7.8.

\section{2,2'-Dihydroxy-3,3,5,5'-tetra-tert-butyl-1,1'-diphenyl (B)}

This compound was synthesized in a similar manner as described for compound $\mathbf{A}$, starting from $11.29 \mathrm{~g}$ of 2,4-di-tert-butylphenol; yield: $21.34 \mathrm{~g}$ (95\%); off-white powder; ${ }^{1} \mathrm{H}$ NMR $\left(400 \mathrm{MHz}, \mathrm{CD}_{2} \mathrm{Cl}_{2}\right): \delta=7.56(\mathrm{~d}, 2 \mathrm{H}, J=2.7 \mathrm{~Hz}), 7.17(\mathrm{~d}, 2 \mathrm{H}$, $J=2.7 \mathrm{~Hz}), 5.17(\mathrm{~s}, 2 \mathrm{H}, \mathrm{OH}), 1.54(\mathrm{~s}, 18 \mathrm{H}, t-\mathrm{Bu}), 1.21(\mathrm{~s}, 18 \mathrm{H}$, $t$-Bu); ${ }^{13} \mathrm{C}$ NMR $\left(75 \mathrm{MHz}, \mathrm{C}_{6} \mathrm{D}_{6}\right): \delta=150.3,143.3,136.7$, 125.7, 124.8, 123.1, 35.3, 34.3, 31.5, 29.7; anal. calcd. for $\mathrm{C}_{28}$ $\mathrm{H}_{42} \mathrm{O}_{2}$ : C 81.9, H 10.3; found: C 81.9, H 9.9.

\section{4,5-(Bis[bis-diethylamido]phosphonito)-9,9- dimethylxanthene $(\mathrm{C})$}

9,9-Dimethylxanthene $(3.00 \mathrm{~g}, 14.3 \mathrm{mmol})$ and TMEDA $(4.14 \mathrm{~g}, 35.7 \mathrm{mmol})$ were dissolved in $50 \mathrm{~mL}$ of diethyl ether and cooled to $-40^{\circ} \mathrm{C}$. $n$-BuLi $(14.3 \mathrm{~mL}$ of a $2.5 \mathrm{M}$ solution in hexanes, $35.7 \mathrm{mmol}$ ) was added via a syringe over a period of $10 \mathrm{~min}$. The mixture was allowed to warm to up to room temperature and was stirred overnight. Subsequently, $\mathrm{CIP}\left(\mathrm{NEt}_{2}\right)_{2}$ $(6.32 \mathrm{~g}, 30.0 \mathrm{mmol})$ was dissolved in $30 \mathrm{~mL}$ of pentane and cooled to $-60^{\circ} \mathrm{C}$. The dilithioxanthene solution was slowly added via a cannula. Subsequently, the reaction mixture was allowed to warm to room temperature and stirred overnight. Solvents were removed under vacuum to leave a yellow solid. $15 \mathrm{~mL}$ pentane were added and the suspension was filtered. Remaining TMEDA was removed by stripping three times with $10 \mathrm{~mL}$ of toluene. Upon cooling to $-25^{\circ} \mathrm{C}$ colourless crys- 
tals were obtained; yield: $5.03 \mathrm{~g}(63 \%) ;{ }^{1} \mathrm{H}$ NMR $(300 \mathrm{MHz}$, $\left.\mathrm{C}_{6} \mathrm{D}_{6}\right): \delta=7.60(\mathrm{~d}, 2 \mathrm{H}, J=7.5 \mathrm{~Hz}), 7.22(\mathrm{~d}, 2 \mathrm{H}, J=7.5 \mathrm{~Hz})$, $7.05(\mathrm{t}, 2 \mathrm{H}, J=7.5 \mathrm{~Hz}), 3.19\left(\mathrm{~m}, 16 \mathrm{H}, \mathrm{CH}_{2}\right), 1.55\left(\mathrm{~s}, 6 \mathrm{H}, \mathrm{CH}_{3}\right)$, $1.06\left(\mathrm{t}, 12 \mathrm{H}, \mathrm{CH}_{3}, J=7.1 \mathrm{~Hz}\right) ;{ }^{13} \mathrm{C} \mathrm{NMR}\left(75 \mathrm{MHz}, \mathrm{C}_{6} \mathrm{D}_{6}\right): \delta=$ 151.0, 130.6, 130.1, 129.5, 126.0, 122.4, $43.3\left(\mathrm{CH}_{2}\right), 33.9$ $\left(\mathrm{CMe}_{2}\right), 32.7\left(\mathrm{CMe}_{2}\right), 14.5\left(\mathrm{CH}_{3}\right) ;{ }^{31} \mathrm{P}\left\{{ }^{1} \mathrm{H}\right\}$ NMR (162 MHz, $\mathrm{C}_{6}$ $\left.\mathrm{D}_{6}\right): \delta=92.3$ (s); anal. calcd for $\mathrm{C}_{31} \mathrm{H}_{51} \mathrm{~N}_{4} \mathrm{OP}_{2}: \mathrm{C} 66.6, \mathrm{H} 9.4, \mathrm{~N}$ 10.0; found: C 66.3, H 9.3, N 9.9.

\section{4,6-(Bis[bis-diethylamido]phosphonito)-2,8- dimethylphenoxathiin (D)}

This product was synthesized in a similar manner as described for compound $\mathbf{C}$, starting from $3.26 \mathrm{~g}(14.2 \mathrm{mmol})$ of 2,8-dimethylphenoxathiin. Yield: $3.55 \mathrm{~g}(43 \%)$; light yellow crystals; ${ }^{1} \mathrm{H}$ NMR $\left(300 \mathrm{MHz}, \mathrm{C}_{6} \mathrm{D}_{6}\right): \delta=7.28(\mathrm{~s}, 2 \mathrm{H}), 6.74(\mathrm{~s}, 2 \mathrm{H}), 3.21$ $\left(\mathrm{m}, 16 \mathrm{H}, \mathrm{CH}_{2}\right), 2.09\left(\mathrm{~s}, 6 \mathrm{H}, \mathrm{CH}_{3}\right), 1.13\left(\mathrm{t}, 12 \mathrm{H}, \mathrm{CH}_{2} \mathrm{CH}_{3}, J=\right.$ $7.0 \mathrm{~Hz}) ;{ }^{13} \mathrm{C}$ NMR $\left(75 \mathrm{MHz}, \mathrm{C}_{6} \mathrm{D}_{6}\right): \delta=151.0,132.8,131.0$, 127.7, 127.1, 118.9, $43.5\left(\mathrm{CH}_{2}\right), 20.7\left(\mathrm{CH}_{3}\right), 14.8\left(\mathrm{CH}_{2} \mathrm{CH}_{3}\right)$; ${ }^{31} \mathrm{P}\left\{{ }^{1} \mathrm{H}\right\}$ NMR $\left(162 \mathrm{MHz}, \mathrm{C}_{6} \mathrm{D}_{6}\right): \delta=90.4(\mathrm{~s})$.

\section{4,5-Bis\{di[(2-tert-butyl)phenyl]phosphonito\}-9,9- dimethylxanthene (1)}

Both A (2.11 g, $3.58 \mathrm{mmol})$, 2-tert-butylphenol (2.15 g, $14.3 \mathrm{mmol}$ ) and $2 \mathrm{~mol} \%$ of tetrazole were dissolved in $20 \mathrm{~mL}$ of di(2-methoxyethyl) ether. The reaction mixture was heated to $135^{\circ} \mathrm{C}$ for 3 days, while the diethylamine formed during reaction was removed under vacuum twice a day. Solvent was removed under vacuum to give a light yellow solid. It was dissolved in $10 \mathrm{~mL}$ of dichloromethane and after layering of the solution with $10 \mathrm{ml}$ of ethanol a pure white powder precipitated; yield: $1.40 \mathrm{~g}(45 \%) ;{ }^{1} \mathrm{H}$ NMR $\left(400 \mathrm{MHz}, \mathrm{C}_{6} \mathrm{D}_{6}\right): \delta=8.15$ $\left(\mathrm{dd}, 2 \mathrm{H},{ }^{1} J=7.2 \mathrm{~Hz},{ }^{2} J=1.2 \mathrm{~Hz}\right), 7.26\left(\mathrm{dd}, 4 \mathrm{H},{ }^{1} J=8 \mathrm{~Hz},{ }^{2} J=\right.$ $1.6 \mathrm{~Hz}), 7.17\left(\mathrm{dd}, 2 \mathrm{H},{ }^{1} J=8 \mathrm{~Hz},{ }^{2} J=1.6 \mathrm{~Hz}\right), 7.14\left(\mathrm{~d}, 4 \mathrm{H},{ }^{1} J=\right.$ $\left.8 \mathrm{~Hz},{ }^{2} J=2 \mathrm{~Hz}\right), 7.0\left(\mathrm{t}, 2 \mathrm{H},{ }^{1} J=7.6 \mathrm{~Hz}\right), 6.86\left(\mathrm{t}, 4 \mathrm{H},{ }^{1} J=8 \mathrm{~Hz}\right.$ $\left.{ }^{2} J=2.4 \mathrm{~Hz}\right), 6.81\left(\mathrm{t}, 4 \mathrm{H},{ }^{1} J=7.6 \mathrm{~Hz},{ }^{2} J=1.6 \mathrm{~Hz}\right), 1.35(\mathrm{~s}, 6 \mathrm{H}$, $\left.\mathrm{CH}_{3}\right), 1.32(\mathrm{~s}, 36 \mathrm{H}, t-\mathrm{Bu}) ;{ }^{13} \mathrm{C}$ NMR $\left(100 \mathrm{MHz}, \mathrm{C}_{6} \mathrm{D}_{6}\right): \delta=$ 155.3, 139.4, 130.5, 129.0, 128.7, 127.4, 127.1, 124.1, 122.7, 119.2, 119.1, 118.9, 34.7, 31.4, 30.1; ${ }^{31} \mathrm{P}\left\{{ }^{1} \mathrm{H}\right\}$ NMR $(162 \mathrm{MHz}$, $\left.\mathrm{C}_{6} \mathrm{D}_{6}\right): \delta=147.8(\mathrm{~s})$; anal. calcd. for $\mathrm{C}_{55} \mathrm{H}_{64} \mathrm{O}_{5} \mathrm{P}_{2}: \mathrm{C} 76.2, \mathrm{H} 7.4$ found: C 76.3, H 7.4. MS (MaldiTOF): $m / z(\%)=899.45(100)$ $[\mathrm{M}+2 \mathrm{O}]^{+}$.

\section{4,5-(Bis\{di[(3,5-di-tert-butyl)phenyl]phosphonito\}-9,9- dimethylxanthene (2)}

Starting from $\mathbf{C}$ (4.32 g, $7.73 \mathrm{mmol}$ ) and 3,5-bis(tert-butyl)phenol $(6.35 \mathrm{~g}, 30.9 \mathrm{mmol})$, compound 2 was obtained as a white powder in analogy to the synthetic procedure described for ligand 1; yield: $4.57 \mathrm{~g}(54 \%) ;{ }^{1} \mathrm{H}$ NMR $\left(400 \mathrm{MHz}, \mathrm{C}_{6} \mathrm{D}_{6}\right): \delta=8.15$ $(\mathrm{dd}, 2 \mathrm{H}, J=7.6 \mathrm{~Hz}, J=1.2 \mathrm{~Hz}), 7.32(\mathrm{~d}, 8 \mathrm{H}, J=1.6 \mathrm{~Hz}), 7.15(\mathrm{t}$, $4 \mathrm{H}, J=1.6 \mathrm{~Hz}), 7.07(\mathrm{dd}, 6 \mathrm{H}, J=7.6 \mathrm{~Hz}, J=1.6 \mathrm{~Hz}), 6.92(\mathrm{t}$, $2 \mathrm{H}, J=7.6 \mathrm{~Hz}), 1.25\left(\mathrm{~s}, 6 \mathrm{H}, \mathrm{CH}_{3}\right), 1.14(\mathrm{~s}, 72 \mathrm{H}, t-\mathrm{Bu})$; ${ }^{13} \mathrm{C}$ NMR $\left(100 \mathrm{MHz}, \mathrm{C}_{6} \mathrm{D}_{6}\right): \delta=155.8,152.2,130.0,129.5$, $128.5,128.3,117.3,115.5,115.4,34.8,31.8,31.4 ;{ }^{31} \mathrm{P}\left\{{ }^{1} \mathrm{H}\right\} \mathrm{NMR}$ $\left(162 \mathrm{MHz}, \mathrm{C}_{6} \mathrm{D}_{6}\right): \delta=148.4$ (s); anal. calcd. for $\mathrm{C}_{71} \mathrm{H}_{96} \mathrm{O}_{5} \mathrm{P}_{2}: \mathrm{C}$ 78.1, H 8.9; found: C 78.0, H 8.6; MS (MaldiTOF): $m / z(\%)=$ $1123.72(100)[\mathrm{M}+2 \mathrm{O}]^{+}$.

\section{4,6-Bis\{di[(2-tert-butyl)phenyl]phosphonito\}-2,8- dimethylphenoxathiin (3)}

Starting from $2.30 \mathrm{~g}(5.20 \mathrm{mmol})$ of $\mathbf{D}$ and $3.12 \mathrm{~g}(20.8 \mathrm{mmol})$ of 2-tert-butylphenol, compound 3 was obtained as a white powder in analogy to the synthetic procedure described for ligand 1; yield: $1.61 \mathrm{~g}(35 \%) ;{ }^{1} \mathrm{H}$ NMR $\left(400 \mathrm{MHz}, \mathrm{C}_{6} \mathrm{D}_{6}\right): \delta=7.87$ $(\mathrm{s}, 2 \mathrm{H}), 7.26(\mathrm{~m}, 2 \mathrm{H}, J=2 \mathrm{~Hz}), 7.22\left(\mathrm{dd}, 1 \mathrm{H},{ }^{1} J=7.6 \mathrm{~Hz},{ }^{2} J=\right.$ $1.6 \mathrm{~Hz}), 7.18\left(\mathrm{dd}, 2 \mathrm{H},{ }^{1} J=2.8 \mathrm{~Hz},{ }^{2} J=1.2 \mathrm{~Hz}\right), 7.18(\mathrm{~d}, 2 \mathrm{H}$, $J=9.2 \mathrm{~Hz}), 6.93\left(\mathrm{td}, 1 \mathrm{H},{ }^{1} J=7.6 \mathrm{~Hz},{ }^{2} J=2 \mathrm{~Hz}\right), 6.81(\mathrm{dd}, 4 \mathrm{H}$, $\left.{ }^{1} J=2.8 \mathrm{~Hz},{ }^{2} J=1.2 \mathrm{~Hz}\right), 6.81(\mathrm{~d}, 4 \mathrm{H}, J=9.2 \mathrm{~Hz}), 6.67(\mathrm{~d}, 1 \mathrm{H}$, $J=1.2 \mathrm{~Hz}), 6.50\left(\mathrm{dd}, 1 \mathrm{H}, J_{1}=7.6 \mathrm{~Hz}, J_{2}=1.2 \mathrm{~Hz}\right), 1.47(\mathrm{~s}, 6 \mathrm{H}$, $\left.\mathrm{CH}_{3}\right), 1.34(\mathrm{~s}, 36 \mathrm{H}, t-\mathrm{Bu}) ;{ }^{13} \mathrm{C}$ NMR $\left(100 \mathrm{MHz}, \mathrm{C}_{6} \mathrm{D}_{6}\right): \delta=$ 155.5, 154.7, 139.4, 134.8, 130.2, 129.6, 128.1, 127.9, 126.9, 123.0, 120.0, 118.9, 118.9, 116.7, 34.7, 30.1, 29.7; ${ }^{31} \mathrm{P}\left\{{ }^{1} \mathrm{H}\right\} \mathrm{NMR}$ (162 MHz, $\left.\mathrm{C}_{6} \mathrm{D}_{6}\right): \delta=145.8$ (s); MS (MaldiTOF): $\mathrm{m} / z$ (\%)= $917.49(100)[\mathrm{M}+2 \mathrm{O}]^{+}$; a correct microanalysis could not be obtained.

\section{4,6-Bis\{di[(3,5-di-tert-butyl)phenyl]phosphonito\}-2,8- dimethylphenoxathiin (4)}

Starting from $2.00 \mathrm{~g}(3.47 \mathrm{mmol})$ of $\mathbf{D}$ and $2.85 \mathrm{~g}(13.87 \mathrm{mmol})$ of 3.5-di-tert-butylphenol, compound 4 was obtained as a white powder in analogy to the synthetic procedure described for ligand 1; yield: $2.08 \mathrm{~g}(54 \%) ;{ }^{1} \mathrm{H}$ NMR $\left(400 \mathrm{MHz}, \mathrm{C}_{6} \mathrm{D}_{6}\right): \delta=7.75$ $(\mathrm{s}, \mathrm{br}, 2 \mathrm{H}), 7.32(\mathrm{~d}, 8 \mathrm{H}, J=1.4 \mathrm{~Hz}), 7.16(\mathrm{t}, 4 \mathrm{H}, J=1.4 \mathrm{~Hz}), 6.61$ $(\mathrm{d}, 2 \mathrm{H}, J=1.6 \mathrm{~Hz})(16$ aromatic protons $), 1.22\left(\mathrm{~s}, 6 \mathrm{H}, \mathrm{CH}_{3}\right)$, $1.16(\mathrm{~s}, 72 \mathrm{H}, t-\mathrm{Bu}) ;{ }^{13} \mathrm{C}$ NMR $\left(100 \mathrm{MHz}, \mathrm{C}_{6} \mathrm{D}_{6}\right): \delta=155.62$, $152.30,134.3,129.77,129.72,128.40,125.52,119.8,117.39$, 115.41, 115.37, 115.33, 110.1, 34.82, 31.39, 20.19; ${ }^{31} \mathrm{P}\left\{{ }^{1} \mathrm{H}\right\}$ NMR $\left(162 \mathrm{MHz}, \mathrm{C}_{6} \mathrm{D}_{6}\right)$ : $\delta 144.7$ (s); anal. calcd. for $\mathrm{C}_{70} \mathrm{H}_{94} \mathrm{O}_{5} \mathrm{P}_{2} \mathrm{~S}: \mathrm{C}$ 75.8, H 8.5; found: C 75.8, H 8.1; MS (MaldiTOF): $m / z(\%)=$ $1141.91(100)[\mathrm{M}+2 \mathrm{O}]^{+}$.

\section{4,5-Bis $\left\{\right.$ dibenzo $[d, f]-2,4,3^{\prime}, 5^{\prime}$-tetra-tert-butyl- [1,3,2]dioxaphosphepino\}-9,9-dimethylxanthene (5)}

Starting from $3.52 \mathrm{~g}(6.30 \mathrm{mmol})$ of $\mathbf{C}$ and $5.17 \mathrm{~g} \mathrm{(12.60} \mathrm{\textrm {mmol } )}$ of $\mathbf{B}$, compound $\mathbf{5}$ was obtained as a white powder in analogy to the synthetic procedure described for ligand $\mathbf{1}$. The reaction time was increased to 4 days; yield: $5.82 \mathrm{~g}$ (85\%); ${ }^{1} \mathrm{H}$ NMR $\left(400 \mathrm{MHz}, \mathrm{C}_{6} \mathrm{D}_{6}\right): \delta=7.62(\mathrm{~d}, 2 \mathrm{H}, J=6.8 \mathrm{~Hz}), 7.50(\mathrm{~d}, 1 \mathrm{H}$, $J=2 \mathrm{~Hz}), 7.48(\mathrm{~d}, 3 \mathrm{H}, J=2.4 \mathrm{~Hz}), 7.35(\mathrm{~d}, 3 \mathrm{H}, J=2.4 \mathrm{~Hz})$, $7.23(\mathrm{~d}, 1 \mathrm{H}, J=2.4 \mathrm{~Hz}), 7.04\left(\mathrm{dd}, 2 \mathrm{H},{ }^{1} J=2 \mathrm{~Hz},{ }^{2} J=1.5 \mathrm{~Hz}\right)$, $6.62(\mathrm{t}, 2 \mathrm{H}, J=7.6 \mathrm{~Hz}), 1.55\left(\mathrm{~s}, 6 \mathrm{H}, \mathrm{CH}_{3}\right), 1.35(\mathrm{~s}, 36 \mathrm{H}, t-\mathrm{Bu})$, $1.27(\mathrm{~s}, 36 \mathrm{H}, t-\mathrm{Bu}) ;{ }^{13} \mathrm{C} \mathrm{NMR}\left(100 \mathrm{MHz}, \mathrm{C}_{6} \mathrm{D}_{6}\right): \delta=146.27$, $140.74,134.61,129.78,128.73,126.84,124.35,123.18,35.58$ (C $t$-Bu front), $35.37\left(\mathrm{CCH}_{3}\right), 34.49$ (C $t$-Bu back), $31.47\left(\mathrm{CH}_{3} t\right.$ $\mathrm{Bu}$ front $), \quad 31.35 \quad\left(\mathrm{CH}_{3} t\right.$-Bu back $), 29.95 \quad\left(\mathrm{CCH}_{3}\right)$; ${ }^{31} \mathrm{P}\left\{{ }^{1} \mathrm{H}\right\} \mathrm{NMR}\left(162 \mathrm{MHz}, \mathrm{C}_{6} \mathrm{D}_{6}\right): \delta=169.0$ (s); anal. calcd. for $\mathrm{C}_{71} \mathrm{H}_{92} \mathrm{O}_{5} \mathrm{P}_{2}$ : C 78.4, $\mathrm{H}$ 8.5; found: $\mathrm{C}$ 78.1, H 8.2; MS (MaldiTOF $): m / z(\%)=1119.66(100)[\mathrm{M}+2 \mathrm{O}]^{+}$.

\section{4,5-Bis $\left\{\right.$ dibenzo $[d, f]-2,5^{\prime}$-di-tert-butyl-4,3'-dimethoxy- [1,3,2]dioxaphosphepino\}-9,9-dimethylxanthene (6)}

Starting from $3.19 \mathrm{~g}(5.72 \mathrm{mmol})$ of $\mathbf{C}$ and $4.10 \mathrm{~g}(11.44 \mathrm{mmol})$ of $\mathbf{A}$, compound $\mathbf{6}$ was obtained as a white powder in analogy to the synthetic procedure described for ligand 5; yield: $4.89 \mathrm{~g}$ 
(87\%); ${ }^{1} \mathrm{H}$ NMR $\left(400 \mathrm{MHz}, \mathrm{C}_{6} \mathrm{D}_{6}\right): \delta=7.6(\mathrm{~d}, 1 \mathrm{H}, J=7.3 \mathrm{~Hz})$, $7.1\left(\mathrm{dd}, 1 \mathrm{H},{ }^{1} J=1.5 \mathrm{~Hz},{ }^{2} J=6.2 \mathrm{~Hz}\right), 7.04(\mathrm{~d}, 2 \mathrm{H}, J=2.9 \mathrm{~Hz})$, $7.02(\mathrm{~d}, 2 \mathrm{H}, J=2.9 \mathrm{~Hz}), 7.0(\mathrm{~m}, 1 \mathrm{H}), 6.7(\mathrm{~d}, 2 \mathrm{H}, J=2.9 \mathrm{~Hz})$, $6.68(\mathrm{t}, 2 \mathrm{H}, J=7.7 \mathrm{~Hz}), 6.65(\mathrm{~d}, 2 \mathrm{H}, J=2.9 \mathrm{~Hz}), 6.61(\mathrm{~d}, 1 \mathrm{H}$, $J=2.9 \mathrm{~Hz})(14$ aromatic protons $), 3.4\left(\mathrm{~s}, 12 \mathrm{H}, \mathrm{OCH}_{3}\right), 1.5(\mathrm{~s}$ $18 \mathrm{H}, t-\mathrm{Bu}), 1.22(\mathrm{~s}, 18 \mathrm{H}, t-\mathrm{Bu}) ;{ }^{13} \mathrm{C} \mathrm{NMR}\left(100 \mathrm{MHz}, \mathrm{C}_{6} \mathrm{D}_{6}\right)$ : $\delta=156.2,154.0,146.3,143.8,142.8,139.8,135.3,129.9,129.8$ $128.7,127.2,123.3,114.8,114.6,113.3,112.8,55.1\left(\mathrm{OCH}_{3}\right)$, $55.0\left(\mathrm{OCH}_{3}\right), 35.4(\mathrm{C} t-\mathrm{Bu}), 35.2(\mathrm{C} t-\mathrm{Bu}), 31.1\left(\mathrm{CH}_{3} t-\mathrm{Bu}\right)$, $30.6\left(\mathrm{CH}_{3}\right), 29.77\left(\mathrm{CH}_{3} t-\mathrm{Bu}\right) ;{ }^{31} \mathrm{P}\left\{{ }^{1} \mathrm{H}\right\} \mathrm{NMR}(162 \mathrm{MHz}$ $\mathrm{C}_{6} \mathrm{D}_{6}$ ): $\delta=168.3$ (s); anal. calcd. for $\mathrm{C}_{47} \mathrm{H}_{44} \mathrm{O}_{13} \mathrm{P}_{2}: \mathrm{C} 64.2$, $\mathrm{H}$ 5.1; found: $\mathrm{C}$ 63.8, H 4.9; MS (MaldiTOF): $\mathrm{m} / \mathrm{z}(\%)=$ $1015.63(100)[\mathrm{M}+2 \mathrm{O}]^{+}$.

\section{4,6-Bis\{dibenzo[ $d, f]-2,4,3^{\prime}, 5^{\prime}$-tetra-tert-butyl- $[1,3,2]$ dioxaphosphepino\}-2,8-dimethylphenoxathiin (7)}

Starting from $3.52 \mathrm{~g}(6.30 \mathrm{mmol})$ of $\mathbf{D}$ and $5.17 \mathrm{~g}(12.60 \mathrm{mmol})$ of $\mathbf{B}$, compound $\mathbf{7}$ was obtained as a white powder in analogy to the synthetic procedure described for ligand 5; yield: $5.82 \mathrm{~g}$ $(83 \%) ;{ }^{1} \mathrm{H}$ NMR $\left(400 \mathrm{MHz}, \mathrm{C}_{6} \mathrm{D}_{6}\right): \delta=7.64\left(\mathrm{~d}, 1 \mathrm{H},{ }^{1} J=\right.$ $6.4 \mathrm{~Hz}), 7.57\left(\mathrm{~d}, 1 \mathrm{H},{ }^{1} J=2.8 \mathrm{~Hz}\right), 7.53\left(\mathrm{~d}, 2 \mathrm{H},{ }^{1} J=2.4 \mathrm{~Hz}\right)$, $7.51\left(\mathrm{~d}, 2 \mathrm{H},{ }^{1} J=2.4 \mathrm{~Hz}\right), 7.39\left(\mathrm{~d}, 2 \mathrm{H},{ }^{1} J=2.4 \mathrm{~Hz}\right), 7.33(\mathrm{~d}, 1 \mathrm{H}$, $\left.{ }^{1} J=2.4 \mathrm{~Hz}\right), 7.17\left(\mathrm{~d}, 2 \mathrm{H},{ }^{1} J=2.4 \mathrm{~Hz}\right), 7.03\left(\mathrm{dd}, 1 \mathrm{H},{ }^{1} J=\right.$ $\left.7.6 \mathrm{~Hz},{ }^{2} \mathrm{~J}=1.6 \mathrm{~Hz}\right)(12$ aromatic protons), $1.52(\mathrm{~s}, 18 \mathrm{H}, t-\mathrm{Bu})$, $1.50\left(\mathrm{~s}, 6 \mathrm{H}, \mathrm{CH}_{3}\right), 1.37(\mathrm{~s}, 18 \mathrm{H}, t-\mathrm{Bu}), 1.29(\mathrm{~s}, 18 \mathrm{H}, t-\mathrm{Bu}), 1.19$ $(\mathrm{s}, 18 \mathrm{H}, t-\mathrm{Bu}) .{ }^{13} \mathrm{C}$ NMR $\left(100 \mathrm{MHz}, \mathrm{C}_{6} \mathrm{D}_{6}\right): \delta=146.27,140.74$, $134.61,129.78,128.73,126.84,124.35,123.18,35.58$ (C $t$-Bu front), $35.37\left(\mathrm{CCH}_{3}\right), 34.49(\mathrm{C} t-\mathrm{Bu}), 31.47\left(\mathrm{CH}_{3} t-\mathrm{Bu}\right), 31.35$ $(t$-Bu $), 29.95\left(\mathrm{CCH}_{3}\right) ;{ }^{31} \mathrm{P}\left\{{ }^{1} \mathrm{H}\right\}$ NMR $\left(162 \mathrm{MHz}, \mathrm{C}_{6} \mathrm{D}_{6}\right): \delta=$ 169.0 (s); anal. calcd. for $\mathrm{C}_{70} \mathrm{H}_{90} \mathrm{O}_{5} \mathrm{P}_{2} \mathrm{~S}$ : C 78.4, $\mathrm{H}$ 8.5; found: $\mathrm{C}$ 78.6, H 8.4. MS (MaldiTOF): $m / z(\%)=1137.70(100)[\mathrm{M}+$ $2 \mathrm{O}]^{+}$.

\section{4,6-Bis $\left\{\right.$ dibenzo $[d, f]-2,5^{\prime}$-di-tert-butyl-4,3' -dimethoxy- $[1,3,2]$ dioxaphosphepino\}-2,8-dimethylphenoxathiin (8)}

Starting from $2.12 \mathrm{~g}(3.67 \mathrm{mmol})$ of $\mathbf{D}$ and $2.63 \mathrm{~g}(7.34 \mathrm{mmol})$ of $\mathbf{A}$, compound $\mathbf{8}$ was obtained as a white powder in analogy to the synthetic procedure described for ligand 5; yield: $2.24 \mathrm{~g}$ (61\%); ${ }^{1} \mathrm{H}$ NMR $\left(400 \mathrm{MHz}, \mathrm{C}_{6} \mathrm{D}_{6}\right): \delta=7.59\left(\mathrm{dd}, 1 \mathrm{H},{ }^{1} J=\right.$ $\left.3.2 \mathrm{~Hz},{ }^{2} J=5.2 \mathrm{~Hz}\right), 7.31\left(\mathrm{~d}, 1 \mathrm{H},{ }^{1} J=1.6 \mathrm{~Hz}\right), 7.14\left(\mathrm{~d}, 1 \mathrm{H},{ }^{1} J=\right.$ $2.8 \mathrm{~Hz}), 7.06\left(\mathrm{~d}, 2 \mathrm{H},{ }^{1} J=3.2 \mathrm{~Hz}\right), 6.89\left(\mathrm{~d}, 1 \mathrm{H},{ }^{1} J=3.2 \mathrm{~Hz}\right)$, $6.74\left(\mathrm{~d}, 2 \mathrm{H},{ }^{1} J=3.2 \mathrm{~Hz}\right), 6.69\left(\mathrm{~d}, 1 \mathrm{H},{ }^{1} J=3.2 \mathrm{~Hz}\right), 6.60(\mathrm{~d}, 1 \mathrm{H}$, $\left.{ }^{1} J=3.2 \mathrm{~Hz}\right), 6.56\left(\mathrm{~d}, 2 \mathrm{H},{ }^{1} J=2.8 \mathrm{~Hz}\right), 3.31\left(\mathrm{~s}, 6 \mathrm{H}, \mathrm{OCH}_{3}\right), 3.29$ $\left(\mathrm{s}, 6 \mathrm{H}, \mathrm{OCH}_{3}\right), 1.46(\mathrm{~s}, 18 \mathrm{H}, t-\mathrm{Bu}), 1.42\left(\mathrm{~s}, 6 \mathrm{H}, \mathrm{CH}_{3}\right), 1.35(\mathrm{~s}$, $18 \mathrm{H}, t-\mathrm{Bu}) ;{ }^{13} \mathrm{C}$ NMR $\left(100 \mathrm{MHz}, \mathrm{C}_{6} \mathrm{D}_{6}\right): \delta=167.40,156.27$, $154.81,154.02,146.30,143.91,143.01,141.77,140.96,139.41$, $135.20,133.96,133.23,132.67,130.64,130.28,129.14,128.92$, $128.28,128.13,127.97,127.96,127.88,127.73,127.65,125.04$, $119.26,115.51,115.10,114.79,114.68,114.50,113.55,113.53$, 113.47, 112.16, $67.88\left(\mathrm{OCH}_{3}\right), 55.00\left(\mathrm{OCH}_{3}\right), 39.04(\mathrm{C} t$ - Bu $)$, $31.29(\mathrm{C} t-\mathrm{Bu}), 30.71\left(\mathrm{CH}_{3}\right), 30.66\left(\mathrm{CH}_{3} t-\mathrm{Bu}\right), 29.65\left(\mathrm{CH}_{3} t-\right.$ $\mathrm{Bu}) ;{ }^{31} \mathrm{P}\left\{{ }^{1} \mathrm{H}\right\}$ NMR $\left(162 \mathrm{MHz}, \mathrm{C}_{6} \mathrm{D}_{6}\right): \delta=166.9$ (s); MS (MaldiTOF $): m / z(\%)=1033.37(100 \%)[\mathrm{M}+2 \mathrm{O}]^{+}$; a correct microanalysis could not be obtained.

\section{$\mathrm{NiBr}_{2}(\mathbf{1})$, Complex 9}

Ligand 1 (500 mg, $0.716 \mathrm{mmol}$ ) was dissolved in $40 \mathrm{~mL}$ of THF. To this solution was added $\mathrm{NiBr}_{2}(\mathrm{dme})$ (332 mg, $\left.1.074 \mathrm{mmol}\right)$ in $200 \mathrm{~mL}$ of THF, giving a clear purple reaction mixture that was stirred for 2 days at $70^{\circ} \mathrm{C}$. The mixture was then cooled to room temperature and the solvent was removed under vacuum. The remaining solid was dissolved in $10 \mathrm{~mL}$ of $\mathrm{CH}_{2} \mathrm{Cl}_{2}$ and filtered by cannula to remove any residual solids. The paramagnetic complex was obtained as crystals by layering with pentane $(1: 1)$. Crystals of the paramagnetic complex, suitable for $\mathrm{X}$-ray analysis, were obtained by slow diffusion of pentane into an $\mathrm{Et}_{2} \mathrm{O}$ solution of complex 9; anal. calcd. for $\mathrm{Br}_{2} \mathrm{C}_{55} \mathrm{H}_{64} \mathrm{NiO}_{5} \mathrm{P}_{2}$ : C 60.85, H 5.94; found: $\mathrm{C} 60.73, \mathrm{H} 5.82$.

\section{X-Ray Diffraction: Crystal Structures of 1 and 9}

X-ray intensities were collected on a Nonius KappaCCD diffractometer with rotating anode $(\lambda=0.71073 \AA$, graphite monochromator) at a temperature of $150(2) \mathrm{K}$. The structures were solved with direct methods (SHELXS97, ${ }^{[38]}$ compound 1) or automated Patterson methods (DIRDIF99, ${ }^{[39]}$ compound 9) and refined with SHELXL97 ${ }^{[40]}$ against $\mathrm{F}^{2}$ of all reflections. Non-hydrogen atoms were refined freely with anisotropic displacement parameters; hydrogen atoms were refined as rigid groups. Compound 1 contains an acetonitrile solvent molecule in the asymmetric unit, which was refined with an occupancy of 0.5 . Illustrations, structure calculations, and structure checking were performed with the PLATON package. ${ }^{[41]}$ Further crystallographic details are given in Table 7.

CCDC-226738 (compound 1) and -226739 (compound 9) contain the supplementary crystallographic data for this paper. These data can be obtained free of charge at www.ccdc.cam. ac.uk/conts/retrieving.html [or from the Cambridge Crystallographic Data Centre, 12, Union Road, Cambridge CB21EZ, UK; fax: (internat.) +44-1223/336-033; E-mail: deposit@ccdc. cam.ac.uk].

\section{Nickel-Catalyzed Isomerization of 2M3BN}

Catalyst preformation: A $10 \mathrm{mg} / \mathrm{mL}$ solution of $\mathrm{Ni}(\operatorname{cod})_{2}$ in toluene was freshly prepared and $2 \mathrm{~mL}$ thereof were added to 1.05 molar equivalents of the appropriate ligand in a $10 \mathrm{~mL}$ Schlenk tube. The reaction mixture was stirred at room temperature for $15 \mathrm{~min}$ and $60 \mathrm{~min}$, respectively, yielding an orange solution.

Isomerization: Under stirring 2M3BN ( $282 \mu \mathrm{L}, 40$ equivs.) was added by Eppendorf pipette to the catalyst solution. In those cases where an additional Lewis acid was used, a solution of $\mathrm{AlCl}_{3}\left(280 \mu \mathrm{L}\right.$ of a $260 \mathrm{mM}$ solution in $\mathrm{CH}_{3} \mathrm{CN}, 1.05$ equivs.) was added. The reaction mixture was heated to $90^{\circ} \mathrm{C}$ for one hour. After cooling by means of an ice-bath, an aliquot of the solution was withdrawn for GC analysis.

\section{Acknowledgements}

This work was financially supported by the Eindhoven University of Technology, the National Research School Combination for Catalysis (NRSCC) and BASF AG and in part (A.M.M., M.L. and A.L.S.) by the Netherlands Organisation for Scientific Research (NWO). 
Table 7. Selected crystallographic data for ligand $\mathbf{1}$ and complex $\mathbf{9}$.

\begin{tabular}{|c|c|c|}
\hline & 1 & 9 \\
\hline formula & $\mathrm{C}_{55} \mathrm{H}_{64} \mathrm{O}_{5} \mathrm{P}_{2} \cdot 0.5 \mathrm{C}_{2} \mathrm{H}_{3} \mathrm{~N}$ & $\mathrm{C}_{55} \mathrm{H}_{64} \mathrm{Br}_{2} \mathrm{NiO}_{5} \mathrm{P}_{2}$ \\
\hline formula weight & 887.53 & 1085.53 \\
\hline crystal colour & colorless & blue \\
\hline crystal size $\left[\mathrm{mm}^{3}\right]$ & $0.48 \times 0.12 \times 0.09$ & $0.36 \times 0.18 \times 0.09$ \\
\hline crystal system & monoclinic & monoclinic \\
\hline space group & $P 2_{1} / \mathrm{c}($ no. 14$)$ & $P 2_{1} / \mathrm{c}($ no. 14$)$ \\
\hline$a[\AA]$ & $10.9055(1)$ & $19.2527(2)$ \\
\hline$b[\AA]$ & 26.3694(3) & $12.7521(1)$ \\
\hline$c[\AA]$ & $20.0433(2)$ & $21.5201(2)$ \\
\hline$\beta$ [deg.] & $118.306(1)$ & $103.2033(5)$ \\
\hline$V\left[\AA^{3}\right]$ & $5074.68(10)$ & $5143.79(8)$ \\
\hline$Z$ & 4 & 4 \\
\hline$D_{\text {calcd. }}\left[\mathrm{g} / \mathrm{cm}^{3}\right]$ & 1.162 & 1.402 \\
\hline$\mu\left[\mathrm{mm}^{-1}\right]$ & 0.132 & 2.039 \\
\hline abs. corr. & none & PLATON (MULABS) \\
\hline transmission range & - & $0.67-0.84$ \\
\hline$(\sin \theta / \lambda)_{\max }\left[\AA^{-1}\right]$ & 0.65 & 0.61 \\
\hline refl. collected/unique & $54146 / 11570$ & $55037 / 9581$ \\
\hline parameters/restraints & $601 / 0$ & $600 / 0$ \\
\hline $\mathbf{R}_{1} / w \mathbf{R}_{2}[\mathrm{I}>2 \sigma(\mathrm{I})]$ & $0.0479 / 0.1048$ & $0.0320 / 0.0704$ \\
\hline $\mathrm{R}_{1} / w \mathbf{R}_{2}$ [all refl.] & $0.0858 / 0.1196$ & $0.0484 / 0.0763$ \\
\hline GoF & 1.020 & 1.019 \\
\hline res. Density $\left[\mathrm{e} / \AA^{3}\right]$ & $-0.34 / 0.34$ & $-0.52 / 0.59$ \\
\hline
\end{tabular}

$\mathrm{R}_{1}=\Sigma|| \mathrm{F}_{\mathrm{o}}|-| \mathrm{F}_{\mathrm{c}}|| / \Sigma\left|\mathrm{F}_{\mathrm{o}}\right|$

$w \mathrm{R}_{2}=\left\{\Sigma\left[\mathrm{w}\left(\mathrm{F}_{\mathrm{o}}^{2}-\mathrm{F}_{\mathrm{c}}^{2}\right)^{2}\right] / \Sigma\left[\mathrm{w}\left(\mathrm{F}_{\mathrm{o}}^{2}\right)^{2}\right]\right\}^{1 / 2}$

\section{References and Notes}

[1] a) S. Krill, in: Applied Homogeneous Catalysis with Organometallic Compounds; (Eds.: B. Cornils, W. A. Herrmann), VCH, Weinheim, 2002, 468; b) A. L. Casalnuovo, T. V. RajanBabu, Transition Metals for Organic Synthesis 1998, 1, 91; c) T. V. RajanBabu, A. L. Casalnuovo, in: Comprehensive Asymmetric Catalysis, Vol. 1, Springer, Heidelberg, Berlin, 1999, 367; d) H. E. Bryndza, J. A. Harrelson Jr., in: Aqueous-Phase Organometallic Catalysis, (Eds.: B. Cornils, W. A. Herrmann), VCH, Weinheim, 1998, 393; e) C. A. Tolman, R. J. McKinney, W. C. Seidel, J. D. Druliner, W. R. Stevens, Adv. Catal. 1985, 33, 1.

[2] W. Goertz, P. C. J. Kamer, P. W. N. M. van Leeuwen, D. Vogt, Chem. Commun. 1997, 1521.

[3] W. Goertz, W. Keim, D. Vogt, U. Englert, M. D. K. Boele, L. A. van der Veen, P. C. J. Kamer, P. W. N. M. van Leeuwen, J. Chem. Soc. Dalton Trans. 1998, 2981.

[4] C. A. Tolman and J. W. Faller, in: Homogeneous Catalysis with Metal Phosphine Complexes; (Ed.: L. H. Pignolet), Plenum, New York, 1983, 81.

[5] M. Beller, B. Cornils, C. D. Frohning, C. W. Kohlpainter, J. Mol. Cat. A: Chem. 1995, 104, 17.

[6] For recent reviews, see: F. Ungvary, Coord. Chem. Rev. 2002, 218，1; P. W. N. M. van Leeuwen, C. P. Casey, G. T. Whiteker, in: Rhodium catalyzed hydroformylation, (Eds.: P. W. N. M. van Leeuwen, C. Claver), Kluwer, Amsterdam, 2001, 63.

[7] a) T. J. Devon, G. W. Phillips, T. A. Puckette, J. L. Stavinoha, J. J. Vanderbilt, (to Eastman Kodak), U. S. Patent
4,694,109, 1987; Chem. Abstr. 1988, 108, 7890; b) T. J. Devon, G. W. Phillips, T. A. Puckette, J. L. Stavinoha, J. J. Vanderbilt, (to Eastman Kodak), U.S. Patent 5,332,846, 1994; Chem. Abstr. 1994, 121, 280879.

[8] H. Bahrmann, P. Lappe, W. A. Herrmann, G. P. Albanese, R. B. Manetsberger, (to Hoechst AG), Eur. Patent 646,588, 1994; Chem. Abstr. 1995, 123, 112408.

[9] P. W. N. M. van Leeuwen, P. A. M. Grotenhuis, B. L. Goodall, (to Shell), Eur. Patent 309,056, 1989; Chem. Abstr. 1989, 111, 232086.

[10] C. P. Casey, G. T. Whiteker, M. G. Melville, L. M. Petrovich, J. A. Gavney Jr., D. R. Powell, J. Am. Chem. Soc. 1992, 114, 5535.

[11] E. Billig, A. G. Abatjoglou, D. R. Bryant, (to Union Carbide), U.S. Patents 4,769,498, 4,668,651, and 4,748,261, 1987; Chem. Abstr. 1987, 14, 3081.

[12] K. Sato, Y. Karawagi, M. Takai, T. Ookoshi, (to Mitsubishi), U. S. Patent 5,235,113, 1993; Chem. Abstr. 1993, 118, 191183.

[13] A. van Rooy, P. C. J. Kamer, P. W. N. M. van Leeuwen, K. Goubitz, J. Fraanje, N. Veldman, A. L. Spek, Organometallics 1996, 15, 835.

[14] a) M. T. Reetz, A. Gosberg, R. Goddard, S. H. Kyung, Chem. Commun. 1998, 2077; b) M. T. Reetz, D. Moulin, A. Gosberg, Org. Lett. 2001, 3, 4083; c) A. Zanotti-Gerosa, C. Malan, D. Herzberg, Org. Lett. 2001, 3, 3687.

[15] S. Hillebrand, J. Bruckmann, C. Krüger, M. W. Haenel, Tetrahedron Lett. 1995, 36, 75. 
[16] M. Kranenburg, Y. E. M. van der Burgt, P. C. J. Kamer, P. W. N. M. van Leeuwen, K. Goubitz, J. Fraanje, Organometallics 1995, 14, 3081.

[17] a) A. C. Hewat, PhD thesis, 2000, RWTH Aachen, Germany; b) W. Ahlers, D. Wiebelhaus, R. Paciello, M. Bartsch, R. Baumann, D. Vogt, A. C. Hewat, (to BASF AG) WO 222,261, 2002; Chem. Abstr. 2002, 136, 249380.

[18] W. Goertz, P. C. J. Kamer, P. W. N. M. van Leeuwen, D. Vogt, Chem. Eur. J. 2001, 1614.

[19] A. Buhling, P. C. J. Kamer, P. W. N. M. van Leeuwen, J. W. Elgersma, K. Goubitz, J. Fraanje, Organometallics 1997, 16, 3027.

[20] A. L. Casalnuovo, T. V. RajanBabu, T. A. Ayers, T. H. Warren, J. Am. Chem. Soc. 1984, 106, 9869.

[21] J. I. van der Vlugt, R. Sablong, A. M. Mills, H. Kooijman, A. L. Spek, A. Meetsma, D. Vogt, J. Chem. Soc. Dalton Trans. 2003, 4690.

[22] J. A. J. Jarvis, R. H. B Mais, P. G. Owston, J. Chem. Soc. A. 1968, 1473.

[23] L. J. Guggenberger, Inorg. Chem. 1973, 12, 499.

[24] I. M. Angulo, E. Bouwman, M. Lutz, W. P. Mul, A. L. Spek, Inorg. Chem. 2001, 40, 2073.

[25] D. J. Spielvogel, W. M. Davis, S. L. Buchwald, Organometallics 2002, 21, 3833.

[26] F. H. Allen, O. Kennard, Chem. Des. Autom. News 1993, 8,31 .

[27] a) C. A. Tolman, W. C. Seidel, D. H. Gerlach, J. Am. Chem. Soc. 1972, 94, 2669; b) D. G. Dick, D. W. Stephan, C. F. Campana, Can. J. Chem. 1990, 68, 628.

[28] a) P. C. J. Kamer, J. N. H. Reek, P. W. N. M. van Leeuwen, Acc. Chem. Res. 2001, 34, 895; b) P. W. N. M. van Leeuwen, P. C. J. Kamer, J. N. H. Reek, P. Dierkes, Chem. Rev. 2000, 100, 2741.
[29] a) L. A. van der Veen, P. K. Keeven, P. C. J. Kamer, P. W. N. M. van Leeuwen, J. Chem. Soc. Dalton Trans. 2000, 2105; b) L. A. van der Veen, P. C. J. Kamer, P. W. N. M. van Leeuwen, Angew. Chem. Int. Ed. 1999, $38,336$.

[30] W. Goertz, PhD. Thesis 1998, RWTH Aachen, Germany.

[31] a) R. J. McKinney, W. A. Nugent, Organometallics 1989, 8, 2871; b) R. J. McKinney, R. B. Osborne, (to DuPont de Nemours), U. S. Patent 4,874,884, 1989; Chem. Abstr. 1990, 112, 18038.

[32] Y. T. Chia, W. C. Drinkard, E. N. Squire, (to DuPont de Nemours), U.S. Patent 3,766,237, 1973; Chem. Abstr. 1974, 80, 70373.

[33] N. M. Brunkan, W. D. Jones, J. Organomet. Chem. 2003, $683,77$.

[34] J. Wilting, A. C. Hewat, C. Müller, J. I. van der Vlugt, D. M. Tooke, D. D. Ellis, A. L. Spek, D. Vogt, manuscript in preparation.

[35] C. A. Tolman, J. Chem. Edu. 1986, 3, 199.

[36] J. I. van der Vlugt, R. Sablong, P. C. M. M. Magusin, A. M. Mills, A. L. Spek, D. Vogt, Chem. Eur. J. submitted for publication.

[37] B. Bogdanovic, M. Kröner, G. Wilke, Liebigs Ann. Chem. 1966, 699, 1.

[38] G. M. Sheldrick, SHELXS97, University of Göttingen, Germany, 1997.

[39] P. T. Beurskens, G. Admiraal, G. Beurskens, W. P. Bosman, S. García-Granda, R. O. Gould, J. M. M. Smits, C. Smykalla, The DIRDIF99 program system, University of Nijmegen, The Netherlands, 1999.

[40] G. M. Sheldrick, SHELXL97, University of Göttingen, Germany, 1997.

[41] A. L. Spek, J. Appl. Cryst. 2003, 36, 7. 